\title{
Effects of Using Different Organic Sources in Combination with Mineral Nitrogen Fertilizer on Soil Fertility, Grain Yield, and Maize Quality
}

\author{
Melkamu Hordofa Sigaye \\ Ethiopian Institute of Agricultural Research Institute, Wondo Genet Agri. Research Center \\ P. O. Box 198, Shashemane, Ethiopia \\ Author Email: hordofa.mel@gmail.com
}

\begin{abstract}
Integrated soil fertility management is critical for crop productivity and soil health management. The study was carried out to determine the effects of different organic sources with mineral nitrogen application on soil fertility, grain yield, and maize quality on the Andisols of Sidama, Ethiopia. The treatments were: control, 100\% of RNP(138 N and $92 \mathrm{P}$ ), $100 \%$ of RN from vermicompost, $100 \% \mathrm{RN}$ from conventional compost, $25 \% \mathrm{RNP}+75 \%$ of RNP from vermicompost, $50 \%$ of RNP $+50 \%$ of RNP from vermicompost, $75 \%$ of RNP+25\% of RNP from vermicompost, $25 \%$ of RNP $+75 \%$ of RNP from conventional-compost, $50 \%$ of $\mathrm{RNP}+50 \%$ of $\mathrm{RN}$ from conventional-compost, and $75 \%$ of RNP $+25 \%$ of $\mathrm{RN}$ from conventional-compost. The treatments were arranged in a randomized complete block design and replicated three times. The highest maize grain yield (7494.3 kg ha-1) and biomass yield (18718.0 kg ha-1) were obtained from the applications of 50\% recommended NP fertilizer plus $50 \%$ vermicompost, which is based on recommended $\mathrm{N}$ equivalent respectively. The soil fertility analysis result shows that the combined application of organic with mineral fertilizer had brought significant changes to soil fertility and showed a positive effect on the soil $\mathrm{pH}$, organic carbon content, total nitrogen, CEC, available $\mathrm{P}$, available K, and CEC. Similarly, the use of organic fertilizer in conjunction with mineral fertilizer resulted in a significant change in the protein and oil content of maize. The protein content $\%$ and oil content $\%$ ranges from $7.1 \%-13.9 \%-4.2 \%-7.2 \%$ respectively. These results suggest that an appropriate proportion of organic fertilizer with mineral fertilizer not only provides enough nutrients but also improves the soil environment, leads to increased yields, and plays an important role in maize quality. Therefore, the combined application of this $50 \%$ recommended NP fertilizer plus 50\% vermicompost (based on $\mathrm{N}$ equivalent rate) can be recommended to farmers for production that increases maize yields with an assurance of sustainable soil fertility and quality maize production in, Sidama of Ethiopia.
\end{abstract}

Keywords: Grain yield, Maize, protein and oil content, Organic and Mineral fertilizers

DOI: $10.7176 /$ ALST/92-02

Publication date: February $28^{\text {th }} 2022$

\section{Introduction}

Maize (Zea mays L.) is a major grain crop grown all over the world. It is Ethiopia's third most important cereal crop, after rice and wheat, and Africa's fifth-largest producer. Smallholder farmers account for $94 \%$ of agricultural output, with area coverage (17\%) and production $(26 \%)$ totaling around 6.5 million tons (CSA, 2019). However, due to low soil fertility and low levels of inputs use, average estimated maize yields for smallholder farmers in Ethiopia are around $3.2 \mathrm{t} \mathrm{ha}^{-1}$, which is much lower than the yield recorded under demonstration plots of 5-6 tha $\mathrm{ha}^{-1}$. Low soil fertility and low levels of input use are some of Ethiopia's major crop production constraints (Abreha et al., 2013 and CSA, 2019).

Because deteriorating soil fertility is a major restriction for maize production, achieving a high maize yield necessitates an appropriate and balanced supply of nutrients. One of the key causes of low yields in most African countries is the lack of or imbalanced application of fertilizer, as well as inadequate or excessive fertilizer. Furthermore, the recently acquired soil inventory data revealed that most nutrients are deficient in Ethiopian soils, including nitrogen (86\%), phosphorus (99\%), potassium (7\%), sulfur (92\%), born (65\%), zinc (53\%), copper, manganese, and iron (Ethio-SIS, 2016). As a result, employing low-cost solutions to address soil nutrient deficits and crop production decreases was critical. This includes, for example, the use of organic and mineral fertilizers in combination, as well as various forms of integrated soil fertility management (Palm et al., 200, Okalebo and Nandwa 1997).

Many researchers have found improved maize yields when using a balanced blend of high-quality organic inputs and mineral fertilizers, as opposed to using only mineral fertilizers (Khan et al., 2016, Usman et al., 2015 and Endris and Dawid 2015). This supports the findings of Negassa et al. (2004b), who discovered that combining NP and FYM yielded higher yields than using either NP or FYM alone for maize cultivation. Similarly, Ahmad et al. (2013) showed that combining $50 \% \mathrm{~N}$ from FYM with $50 \%$ NPK from mineral fertilizers resulted in the highest grain, biological yields, and maximal benefits for smallholder farmers in the 
tropics. Because of the higher total nutrient inputs, organic manure combined with mineral fertilizer resulted in significant grain yield, because of the increased total nutrient inputs in the majority of cases (2016 Sheikha).

Nitrogen supplies an inadequate amount resulting in more proteins formation from the manufactured carbohydrates stored in vegetative cells. According to Mason and D'Croz Mason (2002), N application resulted in higher maize grain protein content. Similarly, Ayub et al. (2003) used several rates of nitrogen and found that $120 \mathrm{~kg} \mathrm{~N} \mathrm{ha}^{-1}$ gave a higher concentration of grain protein content than the other levels of nitrogen. The grain oil content was unaffected by the timing of nitrogen administration (Thomison and Geyer, 2004). Grain quality in terms of protein and oil concentrations is just as significant as grain quantity. A higher production cost will be required if the protein and oil contents are both high. The highest levels of grain oil and protein were seen in plots treated with $200 \mathrm{~kg} \mathrm{~N} \mathrm{ha}^{-1}$ (Sarwar,1993).

Nitrogen application boosted the grain oil concentration of corn, according to Thomison and Geyer (2004). According to Naikwade et al. (2012), the application of compost considerably boosted maize production and nutrient quality. Manure-based fertilization could be used instead of mineral fertilizer to boost maize yields while also improving the soil environment and quality (Wang et al., 2017, and Martinez et al., 2017). Organicmineral fertilizers compound fertilizers have been demonstrated in studies to not only reduce the usage of chemical fertilizers, but also to improve the efficiency and long-term sustainability of agricultural ecosystems (Zhao et al., 2016).

Mineral fertilizers can increase crop yield; however, they have an issue with deteriorating soil qualities, and their cost affordability for smallholder farmers must be addressed. Furthermore, mineral fertilizers alone cannot guarantee long-term agricultural output in many soils since they are ineffective at maintaining and improving soil fertility. As a result, combining organic fertilizers such as vermicompost and traditional composts with mineral fertilizers fertilizer sources was a viable alternative for increasing maize yields while maintaining soil fertility. Moreover, there is limited information on the effects of organic fertilizer use on crop productivity, quality, and soil fertility in the area. Therefore, the study was aimed to determine the effects of different organic sources with mineral nitrogen application on soil fertility, grain yield, and maize quality.

\section{Material and Methods \\ 2.1. Experimental area}

The experiment was performed on a farmer's field in Dore Bafano village, Sidama district, Ethiopia, during 2019 and 2021 and lies in geographic locations between $6^{\circ} 57^{\prime} \mathrm{N}$ and $38^{\circ} 15^{\prime} \mathrm{E}$ to $7^{0} 10^{\prime} \mathrm{N}$ and $38^{\circ} 26^{\prime} \mathrm{E}$ with altitude ranging from 1934-1850 $\mathrm{m}$ above sea level. The site is influenced by a bimodal rainfall system, with long growing seasons from mid-May to mid-September and around $87 \%$ of total rainfall falling between mid-July and the end of August; As a result of this soil erosion and nutrient loss occurred. The average yearly rainfall and temperature are around $800 \mathrm{~mm}-1100 \mathrm{~mm}$, with average monthly minimum and maximum temperatures of $12^{\circ} \mathrm{C}$ and $26.7^{\circ} \mathrm{C}$, respectively. The site's majority soil type is Andosols (FAO, 2014), and maize and haircoat bean were the most common crops planted there.

\subsection{Materials}

HB 546 maize cultivar with It has a 150-day growth period and a yield potential of 6.5 to 8 t ha- 1 . And also, organic source fertilizers (conventional compost and vermicompost), as well as organic nitrogen and phosphorus fertilizers, were used for this experiment.

\subsection{Experimental set-up and procedure}

The experiment was set up in a single layout with three replications using a randomized complete block design (RCBD). It had ten treatments with a combination of organic and mineral fertilizers, with the organic source of fertilizers adjusted for $\mathrm{N}$ equivalence. (Control, $100 \%$ of $R N P$ (138 N and $92 \mathrm{P}$ ), $100 \%$ of RN from vermicompost, $100 \% R N$ from conventional compost, $25 \% R N P+75 \%$ of $R N$ from vermicompost, $50 \%$ of $R N P+50 \%$ of $R N$ from vermicompost, $75 \%$ of $R N P+25 \%$ of $R N$ from vermicompost, $25 \%$ of $R N P+75 \%$ of $R N$ from conventionalcompost, $50 \%$ of $R N P+50 \%$ of $R N$ from conventional-compost, and $75 \%$ of $R N P+25 \%$ of $R N)$. - RNP-which is recommended for Nitrogen and Phosphorous. Each experimental unit was $13.5 \mathrm{~m} 2(4.5 \mathrm{~m} \times 3 \mathrm{~m})$ in size and the maize was planted with a $0.75 \mathrm{~m} * 0.25 \mathrm{~m}$ inter-row spacing. Thus, each experimental unit contained 6 lines of 12 plants each (total of 60 plants per plot). Triple superphosphate (TSP), a phosphorus-containing fertilizer, was given once at sowing to reduce nutrient losses and boost nutrient usage efficiency. Fertilizer containing nitrogen derived from urea and applied twice in the row: half at sowing and the other half during the peak growth or tasselling stage. Based on nitrogen equivalency, organic fertilizer (vermicompost and traditional compost) was applied 20 days before sowing. Organic fertilizer (vermicompost and conventional compost) was applied 20 days before sowing based on nitrogen equivalency. All other agronomic management practices were applied as per recommendation for the variety. 


\subsection{Soil and plant data collection}

Plant height, ear height, ear length, above-ground biomass yield, straw yield, grain yield, 1000 seed weight, and harvest index were among the crop yield and yield component data collected. Before treatment applications, composite soil samples are collected at random depths of $0-20 \mathrm{~cm}$ throughout all experimental plots, and soil samples were also collected immediately after harvesting the crop to examine changes in soil chemical characteristics owing to treatment application. The soil samples were air-dried, ground to pass through a $2 \mathrm{~mm}$ sieve, and then processed and evaluated for soil texture, $\mathrm{pH}$, organic matter, total nitrogen, available phosphorous, total sulfur, and cation exchange capacity using standard procedures. To quantify maize grain protein content $\%$ and oil content $\%$, sample grains were obtained from each treatment.

\subsection{Statistical Analysis}

The data were analyzed by using one-way analysis of variance (ANOVA) using statistical analysis software (SAS) version 9.4, (SAS, 2014). Whenever the effects of the treatments were significant, mean separations were made using the least significant difference (LSD) test at $(\mathrm{p} \leq 0.05)$ level of probability test by proc-mixed analysis (Gomez and Gomez,1984.).

\section{Result and Discussion}

\subsection{Chemical properties of vermicompost and conventional compost}

Table 2 shows the chemical compositions of vermicompost and common compost. The $\mathrm{pH}$ water $(1: 2.5)$ of vermicompost and normal compost was 7.8 and 7.4, respectively, according to the results. According to Hazelton and Murphy (2007), the organic materials were slightly alkaline, providing them the best for plant growth. The vermicompost had $2.73 \%$ total nitrogen and $28.1 \%$ organic carbon, respectively, whereas the normal compost contained $1.93 \%$ total nitrogen and $30.1 \%$ organic carbon. This means that vermicompost has a higher overall nitrogen content than regular compost. This could be attributed to earthworms adding organic nitrogen to the environment through excretory products, mucus, body fluid, enzymes, and even decaying worm tissues. In vermicomposting, earthworms increased the overall N level, according to Suthar (2007). During vermicomposting of wastes from various sources, Yadav et al. (2010) reported total organic carbon reduction values ranging from 26 to $66 \%$. Suthar (2009) found that the final product had a higher total nitrogen content (range $2.49-3.17 \%$ ), which he attributed to the quality of the worm-feeding substrate and likely mineralization of the organic materials. Vermicompost and normal compost had available P of $1.25 \mathrm{~g} \mathrm{~kg}^{-1}$ and $0.95 \mathrm{~g} \mathrm{~kg}^{-1}$, respectively. Marlin and Rajesh Kumar (2012) found a similar finding, suggesting that vermicomposting had a higher available P. (2.68-3.61\%).

The earthworm gut phosphatases release some of the available P content from the organic matter during vermicomposting, and further release of $\mathrm{P}$ could be attributed to the $\mathrm{P}$-solubilizing microorganisms present in the worm casts, which cause conversion of phosphorus $(\mathrm{P})$ to forms that are more bio-available to plants (Goswami et al., 2008). Vermicompost (1.69) and regular compost both have a high $\mathrm{K}$ content $(0.92)$. $\mathrm{K}$ values of $0.54 \%$ to $1.72 \%$ have been recorded in earlier studies (Waseem et al. 2013). The content of vermicompost and normal compost has a C: $\mathrm{N}$ ratio of $28.1 \%$ and $30.1 \%$, respectively. The drop in the carbon/nitrogen ratio, according to Kaushik and Garg (2003), is related to the rapid decomposition of organic waste, as well as mineralization and stabilization throughout the vermicomposting process.

Table 1 Some physic-chemical properties of vermicompost, and conventional compost

\begin{tabular}{lll}
\hline Properties & Vermicompost & Conventional Compost \\
\hline $\mathrm{pH} \mathrm{H} \mathrm{H}_{2} \mathrm{O}(1: 2.5)$ & 7.8 & 7.4 \\
\hline Organic Carbon $(\%)$ & 28.1 & 30.1 \\
\hline Total Nitrogen $(\%)$ & 2.72 & 1.93 \\
\hline Available P $(\mathrm{g} \mathrm{kg}-1)$ & 1.25 & 0.95 \\
\hline $\mathrm{K}(\mathrm{g} \mathrm{kg}-1)$ & 1.69 & 0.92 \\
\hline Total S mg kg-1 & -- & -- \\
\hline $\mathrm{CEC}\left(\mathrm{Cmol}^{+} \mathrm{kg}^{-1}\right)$ & -- & -- \\
\hline $\mathrm{C}: \mathrm{N}$ & 10.33 & 15.59 \\
\hline $\mathrm{MC} \%$ & 58.1 & 68.5 \\
\hline
\end{tabular}

\subsection{Physicochemical Properties of Experimental Field Soil}

The findings of the research revealed that the experimental site's soil particle size distribution was dominated by sand, silt, and clay $(39,31$, and $30 \%$, respectively) (Table 2). The soil textural classes of the site were silt loam and clay, according to FAO (2014) soil textural classification. The $\mathrm{pH}$ content of the soil at the site is near neutral (6.7), according to soil characteristics (Table 2). The soil in the experimental soil, according to Tekalign (1991), was neutral. Soil pH affects plant growth by regulating the activity of soil microbes and altering the 
solubility and availability of most critical plant nutrients, particularly micronutrients like $\mathrm{Fe}, \mathrm{Zn}, \mathrm{B}, \mathrm{Cu}$, and $\mathrm{Mn}$ (Sumner, 2000). According to the results of the analysis, the available P content was $6.42 \mathrm{mg} \mathrm{kg}^{-1}$ (Table 2), which is considered low (Cottenie,1980). Low soil test $\mathrm{P}$ values near to or below $10 \mathrm{mg} \mathrm{P} \mathrm{kg}^{-1}$, the level below which P responses are expected, were reported by Okalebo et al. (1993). According to Tekalign's (1991) classification, the total nitrogen content of the sites was 0.19 , which is considered excessive. According to Tekalign's (1991) classification, organic carbon content was 3.01\%, which is considered high. The site's total S content is $22.51 \mathrm{mg} \mathrm{kg}^{-1}$. The available $\mathrm{S}$ content of the soil in the study area is low, according to Havlin et al. (2003). According to Hazelton and Murphy's (2007) classification, the soils' cation exchange capacity (CEC) was $29 \mathrm{Cmol}+\mathrm{kg}^{-1}$, which is moderate. (See Table 2)

Table 2. Some physic-chemical properties of the experiment field soil

\begin{tabular}{ll}
\hline Parameters & Level \\
\hline Texture & \\
\hline Sand & 39 \\
\hline Silt & 31 \\
\hline Clay & 30 \\
\hline Textural Class & Silt Loam \\
\hline Available P $\left(\mathrm{mg} \mathrm{kg}_{2}^{-1} \mathrm{O}(1: 2.5)\right.$ & 6.7 \\
\hline Total Nitrogen $(\%)$ & 6.42 \\
\hline Organic Carbon $(\%)$ & 0.19 \\
\hline $\mathrm{K}\left(\mathrm{Cmol} \mathrm{kg}^{-1}\right)$ & 3.01 \\
\hline Total S mg kg-1 & 2.41 \\
\hline $\mathrm{CEC}\left(\mathrm{Cmol}^{+} \mathrm{kg}^{-1}\right)$ & 22.51 \\
\hline
\end{tabular}

\subsection{Soil chemical characteristics after crop harvest}

After the final maize harvest, soil samples were collected from each experimental unit to assess the effects of organic and mineral fertilizers fertilizer on soil fertility. As a result, the combined application of organic and mineral fertilizers fertilizer resulted in a significant shift in soil fertility, with positive effects on soil $\mathrm{pH}$, organic carbon content, total nitrogen, CEC, available $\mathrm{P}$, Available $\mathrm{K}$, and $\mathrm{CEC}$ (Table 3). The soil pH significantly improved as a result of the various treatments, reaching a maximum of 7.9 within plot treated with $50 \%$ vermicompost based on N equivalency plus $50 \%$ prescribed NP fertilizer ha- ${ }^{1}$. The minimum, on the other hand, was seen at the control plot (non-fertilized). This indicates that comprehensive nutrient management has improved soil fertility (Khan et al., 2016).

Similarly, based on $\mathrm{N}$ equivalence with $50 \%$ recommended NP fertilizer ha $\mathrm{h}^{-1}$, the combined application of $50 \%$ vermicompost and conventional compost gave the highest soil organic carbon content of $3.5 \%$ and $2.9 \%$, respectively (Table 3). The control or unfertilized plot had the lowest soil organic carbon content, followed by the application of organic fertilizer from normal and vermicompost, and a $100 \%$ recommended rate of NP alone (Table 3). Increased organic carbon owing to the application of organic manures resulted in higher crop performance and soil properties.

After applying organic and mineral fertilizers, the total nitrogen, available phosphorus, and CEC levels in the soil increased (Table 3). The combined application of $50 \%$ vermicompost based on $\mathrm{N}$ equivalence plus $50 \%$ prescribed NP fertilizer yielded the highest TN (0.41\%) available phosphorus (19.5 g kg-1) and CEC (36.1 $\mathrm{Cmol} \mathrm{c} \mathrm{kg} \mathrm{k}^{-1}$ ) values. This finding was supported by Mubeen et al. (2013), who showed that combining organic and mineral fertilizers is an effective way to improve nutrient recovery, soil nutrient status, plant growth, and ultimate production. Huang et al. (2007) found that combining organic and mineral fertilizers fertilizer sources boosted synergism and synchronization between nutrient release and plant recovery, resulting in improved crop growth and productivity. Finally, from this study, we found that using a combination of mineral fertilizers and organic fertilizers was the greatest technique for increasing productivity and maintaining soil fertility.

\subsection{Effects of organic and mineral fertilizers on grain yield of maize}

The application of organic and mineral fertilizers can significantly (0.01) increase maize above-ground biomass, grain yield, and straw yield, according to the pulled mean analysis (Table 4). The application of $50 \%$ of recommended NP plus $50 \%$ of $\mathrm{N}$ from vermicompost based on $\mathrm{N}$ equivalence resulted in maximum aboveground biomass yield (18.2 t ha-1) and grain yield (7.5 $\left.\mathrm{t} \mathrm{ha}^{-1}\right)$. Unfertilized or control plots, on the other hand, had the lowest values of above-ground biomass and grain yield. The use of $50 \%$ of recommended NP $+50 \%$ of $\mathrm{N}$ from vermicompost based on $\mathrm{N}$ equivalence showed in grain yield increases of $115 \%, 24 \%$, and $21 \%$, respectively, as compared to the control and application of $100 \%$ of recommended NP fertilizers. Improving N synchronization with combined inputs through direct interactions of organic sources and $\mathrm{N}$ fertilizers has been 
attributed to this increase in grain yield (Vanlauwe et al., 2002b). Table 4 shows that the yield advantage over the control (unfertilized) condition was $115 \%$, demonstrating soil depletion and a strong response to fertilizer application. This is due to the optimal use of organic and mineral fertilizers, which played a role in seed formation and grain filling energy provision. Importantly, these findings are consistent with those of Shisanya et al. (2009), who showed that using a combination of mineral fertilizers and organic nutrients boosted maize yield by $35 \%$. Synergy and synchronization of nutrient release and plant recovery were increased by combining organic and mineral fertilizers nutrient sources, resulting in improved crop yields and productivity.

This supports the findings of Ahmad et al. (2013), who observed that applying $50 \% \mathrm{~N}$ via FYM and $50 \%$ NPK via mineral fertilizers boost maize grain and biological yield. Another study found that combining $50 \%$ organic manure with $50 \%$ urea nitrogen resulted in higher yield and yield components than using both organic or mineral nitrogen alone (Ali et al., 2012). According to Shilpashree et al. (2012), $100 \%(50 \% \mathrm{~N}$ through mineral fertilizers $+50 \% \mathrm{~N}$ through $\mathrm{FYM}$ /vermicompost) and $150 \%(75 \% \mathrm{~N}$ through mineral fertilizers + $75 \% \mathrm{~N}$ through FYM/vermicompost) nitrogen fertilization yielded significantly higher straw and grain yields. The current findings are similar to those of Baloch et al. (2015), Dilshad et al. (2010), and Khan et al. (2016), who found that using a combination of organic and mineral fertilizers sources of nutrients resulted in the maximum maize biological yield. Similarly, the findings are consistent with those of Fanuel and Gifole (2013) and Magda et al, (2015), who found that maximum grain yields may be due to improved growth, development, and dry matter accumulation with proper nutrient supply and an increase in the availability of other plant nutrients with the application of the appropriate nitrogen source.

Table 4. Effects of integrated use of organic and mineral fertilizers on yield of maize in 2019-2021 cropping seasons.

\begin{tabular}{|c|c|c|c|c|c|c|c|c|}
\hline \multirow[b]{3}{*}{ Treatment (kg ha-1) } & \multirow{2}{*}{\multicolumn{2}{|c|}{$\begin{array}{l}\text { Year } \\
2019\end{array}$}} & \multirow{2}{*}{\multicolumn{2}{|c|}{$\begin{array}{l}\text { Year } \\
2020\end{array}$}} & \multirow{2}{*}{\multicolumn{2}{|c|}{$\begin{array}{l}\text { Year } \\
2021\end{array}$}} & \multirow{2}{*}{\multicolumn{2}{|c|}{ polled }} \\
\hline & & & & & & & & \\
\hline & $\begin{array}{l}\text { BM }(\mathrm{t} \\
\text { ha-1) }\end{array}$ & $\begin{array}{l}\text { GY (t ha- } \\
\text { 1) }\end{array}$ & $\begin{array}{l}\text { BM } \\
\text { ha-1) }\end{array} \quad$ (kg & $\begin{array}{l}\text { GY (kg } \\
\text { ha-1) }\end{array}$ & $\begin{array}{l}\text { GY }(\mathrm{t} \\
\text { ha-1) }\end{array}$ & $\begin{array}{l}\text { BM (t } \\
\text { ha-1) }\end{array}$ & $\begin{array}{l}\text { BM }(\mathrm{t} \\
\text { ha-1) }\end{array}$ & $\begin{array}{l}\text { GY } \\
\text { ha-1 })\end{array}$ \\
\hline Control & $9.0^{\mathrm{d}}$ & $2.5^{\mathrm{ab}}$ & $9.7^{\mathrm{d}}$ & $4.1^{\mathrm{d}}$ & $14.8^{c}$ & 10.9 & $11.1^{\mathrm{e}}$ & $3.5^{\mathrm{e}}$ \\
\hline $100 \%$ RNP & $18.9^{\mathrm{a}}$ & $6.4^{\mathrm{a}}$ & $14.2^{\mathrm{bc}}$ & $6.1^{\mathrm{abc}}$ & $18.6^{\mathrm{abc}}$ & 12.9 & $17.2^{\mathrm{ab}}$ & $6.1^{\mathrm{bc}}$ \\
\hline $100 \%$ RN V.C & $11.9^{\mathrm{bcd}}$ & $4.2^{\mathrm{bcd}}$ & $13.9^{\mathrm{cd}}$ & $4.7^{\mathrm{cd}}$ & $15.3^{\mathrm{bc}}$ & 10.5 & $13.6^{\mathrm{d}}$ & $4.6^{\mathrm{e}}$ \\
\hline 100\% RN C.C & $11.5^{\text {bcd }}$ & $4.1^{\mathrm{cd}}$ & $13.3^{\mathrm{cd}}$ & $4.5^{\mathrm{cd}}$ & $15.4^{\mathrm{c}}$ & 10.4 & $13.4^{\mathrm{de}}$ & $4.5^{\mathrm{e}}$ \\
\hline $25 \%$ RNP $+75 \% \mathrm{~V} . \mathrm{C}$ & $11.1^{\mathrm{cd}}$ & $3.6^{\mathrm{de}}$ & $12.1^{\mathrm{cd}}$ & $5.5^{\mathrm{bcd}}$ & $16.1^{\mathrm{abc}}$ & 11.7 & $13.1^{\mathrm{de}}$ & $4.5^{\mathrm{e}}$ \\
\hline $50 \% \mathrm{RNP}+50 \% \mathrm{~V} . \mathrm{C}$ & $18.9^{\mathrm{a}}$ & $6.7^{\mathrm{a}}$ & $19.0^{\mathrm{a}}$ & $7.7^{\mathrm{a}}$ & $19.3^{\mathrm{a}}$ & 11.2 & $18.7^{\mathrm{a}}$ & $7.5^{\mathrm{a}}$ \\
\hline $75 \% \mathrm{RNP}+25 \% \mathrm{~V} . \mathrm{C}$ & $18.5^{\mathrm{a}}$ & $5.7^{\mathrm{ab}}$ & $14.9^{\mathrm{abc}}$ & $4.9^{\mathrm{bcd}}$ & $16.7^{\mathrm{abc}}$ & 11.1 & $16.7^{\mathrm{abc}}$ & $5.4^{\mathrm{cd}}$ \\
\hline $25 \%$ RNP $+75 \%$ C.C & $13.1^{\mathrm{bc}}$ & $4.3^{\mathrm{bcd}}$ & $15.7^{\mathrm{abc}}$ & $5.3^{\mathrm{bcd}}$ & $15.8^{\mathrm{abc}}$ & 10.9 & $14.9^{\mathrm{cd}}$ & $4.8^{\mathrm{de}}$ \\
\hline $50 \%$ RNP $+50 \%$ C.C & $14.5^{\mathrm{b}}$ & $6.2 .4^{\mathrm{a}}$ & $18.4^{\mathrm{ab}}$ & $6.6^{\mathrm{ab}}$ & $19.1^{\mathrm{ab}}$ & 12.6 & $17.4^{\mathrm{ab}}$ & $6.4^{\mathrm{b}}$ \\
\hline $75 \%$ RNP $+25 \%$ C.C & $18.5^{\mathrm{a}}$ & $5.5^{\mathrm{abc}}$ & $12.1^{\mathrm{cd}}$ & $4.7^{\mathrm{cd}}$ & $18.1^{\mathrm{abc}}$ & 13.2 & $16.3^{\mathrm{bc}}$ & $5.1^{\mathrm{de}}$ \\
\hline $\mathrm{CV} \%$ & 13.7 & 18.0 & 17.8 & 20.0 & 13.5 & 20.0 & 15.8 & 17.0 \\
\hline$\underline{\mathrm{LSD}} \leq 0.05$ & 3418.7 & 1520.5 & 4382.2 & 1882.9 & 3902.2 & 4073.5 & 2261.2 & 841.2 \\
\hline
\end{tabular}

Numbers followed by the same letter in the same column are not significantly different at the 5\% probability level; Where: RNP-recommended rate of nitrogen and phosphorous, BM-biomass, GY-grain yield, and t-tone

\subsection{Maize grains protein content and oil content as affected by organic and mineral fertilizers}

The application of different organic and mineral $\mathrm{N}$ fertilizers can significantly $(<0.01)$ increase grain protein $\%$ and oil content $\%$ of maize in all seasons, according to the pulled mean analysis (Table 5). The application of $50 \%$ of recommended NP $+50 \%$ of $\mathrm{N}$ from vermicompost resulted in the highest grain protein content $(13.9 \%)$. In comparison to other treatments, the application of $50 \%$ of recommended $\mathrm{NP}+50 \%$ of $\mathrm{N}$ from vermicompost resulted in the highest grain oil content (7.2\%) (Table 5). The control or unfertilized plot, on the other hand, provided the minimum maize grain protein and oil content $\%$. The lower oil content may be due to the higher supply of nitrogen from the increased fertilizer levels. The findings are consistent with those of (Mohammed et al., 2014 and Fadlalla et al., 2016). 


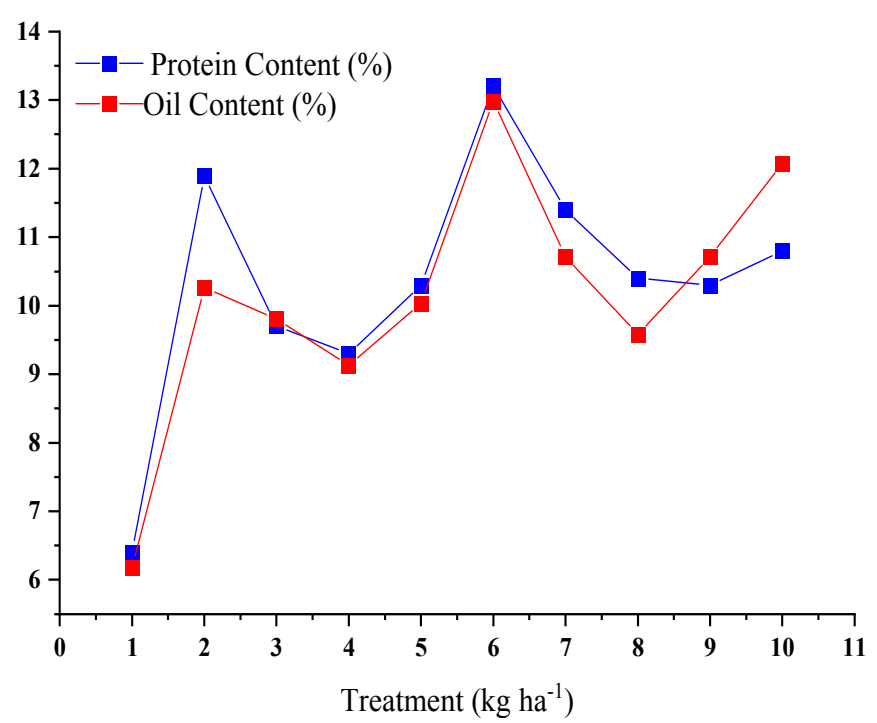

Figure 1. Effects of different organic sources with mineral nitrogen application on Protein Content (\%) and Oil Content (\%) of hybrid maize during 2019 cropping season.

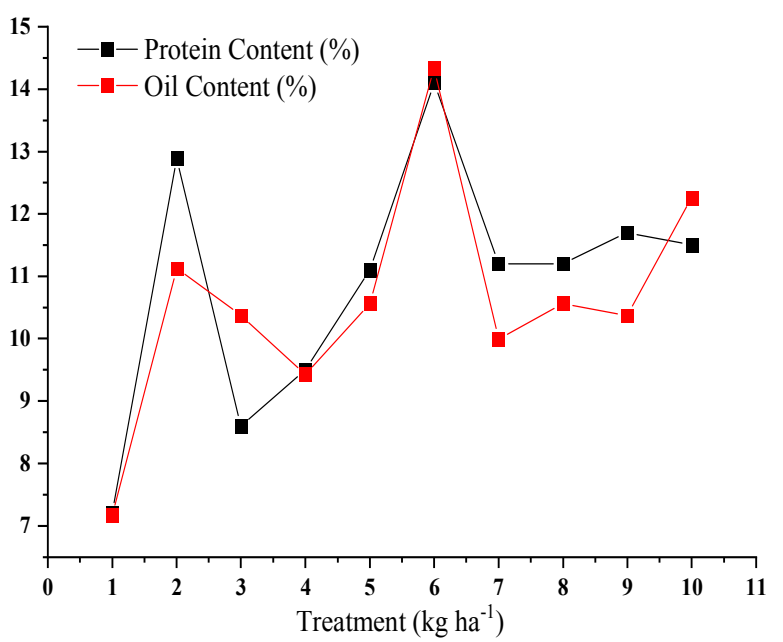

Figure 2. Effects of different organic sources with mineral nitrogen application on Protein Content (\%) and Oil Content (\%) of hybrid maize during 2020 cropping season.

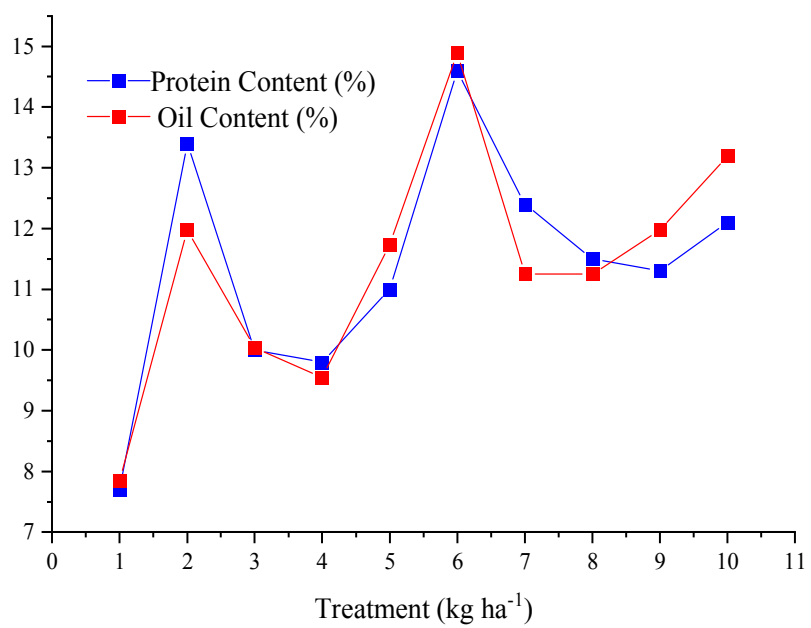

Figure 3. Effects of different organic sources with mineral nitrogen application on Protein Content (\%) and Oil Content (\%) of hybrid maize during 2021 cropping season. 


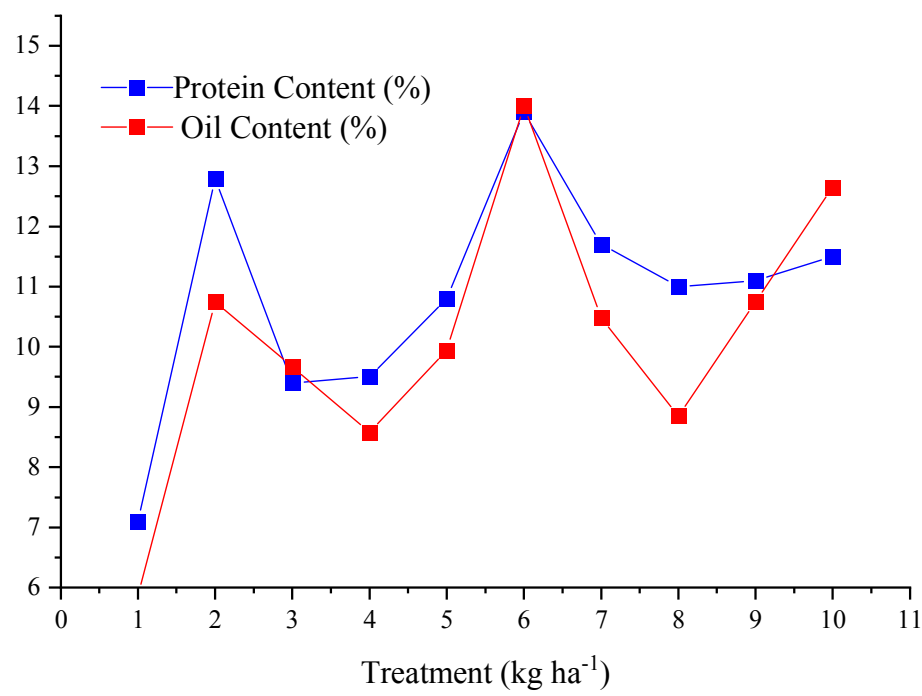

Figure 3. Effects of different organic sources with mineral nitrogen application on Protein Content (\%) and Oil Content (\%) of hybrid maize during 2019-2021 cropping season (polled)

\section{Conclusions and Recommendation}

These findings suggest that combining organic and mineral fertilizers in the right proportions is advantageous to maize yield and soil nutrient balance. The use of a combination of mineral fertilizers and organic fertilizers, as well as the application of $50 \%$ required NP fertilizer $+50 \%$ vermicompost, is advised to boost maize yield and improve soil fertility, according to the findings of this study. Based on $\mathrm{N}$ equivalence with recommended NP fertilizer application, a better grain yield of maize was attained by combining $50 \%$ recommended NP fertilizer with $50 \%$ vermicompost.

The combined application of organic with mineral fertilizer had brought significant change on soil fertility and showed a positive effect on the soil $\mathrm{pH}$, organic carbon content, total nitrogen, CEC, available $\mathrm{P}$, Available K, and CEC. Similarly, the application of organic with mineral fertilizer had brought significant change on protein content $\%$ and oil content $\%$ of maize. These results suggest that an appropriate proportion of organic fertilizer with mineral fertilizer not only provides enough nutrients but also improves the soil environment and leads to increased yields and plays important role in maize quality. Therefore, the combined application of these $50 \%$ recommended NP fertilizer plus 50\% vermicompost (based on $\mathrm{N}$ equivalent rate) were can be recommended to farmers for production that increases maize yields with an assurance of sustainable soil fertility and quality maize production in, Sidama of Ethiopia.

\section{Acknowledgment}

The Ethiopian Institute of Agricultural Research, Natural Resources Management Research, provided funding to the authors to do this work.

\section{Interest Conflicts}

The authors state that the publishing of this paper does not include any conflicts of interest.

\section{REFERENCES}

Abbasi, M.K. and Yousra, M. 2012. Synergistic effects of biofertilizer with organic and chemical N sources in improving soil nutrient status and increasing growth and yield of wheat grown under greenhouse conditions. Plant biosystems, 146:181-189.

Abreha, K., H. Gerekidan, T. Mamo and K. Tesfaye. 2013. Wheat crop response to lime materials and N and P fertilizers in acidic soils of Tsegedie highlands, Northern Ethiopia. Agric. For., 2: 126-135.

Ahmad W, Z. Shah, F. Khan, S. Ali, and W. Malik. 2013. "Maize yield and soil properties as influenced by integrated use of organic, mineral fertilizers and bio-fertilizers in a low fertility soil," Soil Environ., vol.32, pp. 121-129. Available: www.se.org.pk.

Ali K., S. K. Khali, F. Munsif Abdurrab, K. Nawab, A. Z. Khan, A. Kamal, and Z. H. Khan, 2012."Response of maize to various nitrogen sources and tillage practices," Sarhad J. Agric., vol. 28, pp. 9-14.

Ayub, M., R. Ahmad, M.A. Nadeem, B. Ahmad and R.M.A. Khan. 2003. Effect of different levels of nitrogen and seed rates on growth, yield, and quality of maize fodder. Pak. J. Agri. Sci. 40: 140-143.

Baloch, P.A.; Abro, B.A; chandio, A.S.; Depar, N. and Anssari, M.A. 2015. Growth and yield response of maize 
to the integrated use of Gliricidia Sepium, farm manure, and NPK fertilizers. Pakistan J. Agric., Agril. Engg., vet. Sa'.,31(1):14-23.

Cottenie A. 1980. Soil and plant testing as a basis of fertilizer recommendations. FAO soil bulletin38/2. Food and Agriculture Organization of the United Nations, Rome.

CSA (Central Statistical Agency). 2019. Agricultural Sample Surveys. CSA, Addis Ababa, Ethiopia.

Dilshad, M.D., M.I Lone, G. Jilani, M.A. Malik, M. Yousaf, R. Khalid, and F. Shamim. 2010. Integrated Plant Nutrient Management (IPNM) on maize under rainfed conditions. Pak. J. Nutr.,9: 896-901.

Endris S, Dawid J (2015) Yield response of maize to integrated soil fertility management on acidic nitosol of southwestern Ethiopia. J Agron 14: 152-157.

Fadlalla, H.A.; Abukhlaif, H.A.A. and Mohamed, S.S. (2016). Effects of chemical and bio-fertilizers on yield, yield components, and grain quality of maize (Zea mays L.). Afr. J. Agric. Res., 11(45): 4654-4660.

Fanuel, L. and Gifole, G. 2013. Growth and yield response of maize (Zea mays L.) to variable rates of compost and mineral fertilizers fertilizer integration in Wolaita, Southern Ethiopia. Am.J.Plant Nutr.Fert. Technol., $3(2): 43-52$.

FAO (Food and Agriculture Organization). 2014. World Reference Base for Soil Resources International soil classification system for naming soils and creating legends for soil maps. World Soil Resources Reports No. 106. Food and Agriculture Organization of the United Nations (FAO), Rome, Italy.

Gomez AK, and AA Gomez. 1984.Statistical procedure for agricultural research $2^{\text {nd }}$ (Ed.). A Wiley Inter-Science Publication, New York.

Goswami L, Patel AK, Dutta G, Bhattacharyya P, Gogoi N, (2013) Hazard remediation and recycling of tea industry and paper mill bottom ash through vermi-conversion. Chemosphere 92: 708-713.

Havlin JL, Beaton JD, Tisdale SL, Nelson WL (2005) Soil fertility and fertilizers: An introduction to nutrient management. Pearson Prentice Hall, Upper Saddle River, New Jersey, USA.

Hazelton, P., and B. Murphy, 2007. Interpreting soil test results: What do all the numbers mean $2^{\text {nd }}$ Edition. CSIRO Publishing. 152p.

Huang, B., Sun, W.Z., Hao, Y.Z., Hu, J., Yang, R.,Zou, Z., Ding, F., Su, J. 2007. Temporal and spatial variability of soil organic matter and total nitrogen in an agricultural ecosystem as affected by farming practices. Geoderma 139, 336-345

Kaushik P, Garg VK (2003) Vermicomposting of mixed textile mill sludge and cow dung with epigenic earthworm Eisenia foetida.Bioresour Technol 90: 311-316.

Khan S, Mohammad TJ, Bilal A, Tariq S, Wisal A (2016) Yield and yield components of maize as affected by integrated management of sheep manure and urea fertilizer. Middle-East J Agric Res 5: 522-533.

Khan, S.; Mohammad, T.J.; Bilal, A.; Tariq, S. and Wisal, A. 2016). Yield and yield components of maize as affected by integrated management of sheep manure and urea fertilizer. Middle-East J. Agric. Res., 5(4): 522-533.

Magdav, A.E.; Sabar, M.Z. and Mohamed, A.A. 2015. Effect of mineral fertilizer integration with organic manure on growth, yield, and quality of maize (Zea mays L.). J. soil Sci. and Agric. Eng., Mansoura univ., 6(2):165-179.

Marlin CJ, Rajeshkumar KT (2012) A study on the sustainable utility of sugar mill effluent to vermicompost. Adv Appl Sci Res 3: 1092-1097.

Martı 'neza E, Domingo F, Rosello' A, Serra J, Boixadera J. Lloveras J. The effects of dairy cattle manure and mineral N fertilizer on irrigated maize and soil N and organic. Europ. J. Agronomy. 2017; 83: 78-85.

Martínez, E. et al. Long-term effects of pig slurry combined with mineral nitrogen on maize in a Mediterranean irrigated environment. Field Crops Res. 214, 341-349. https://doi.org/10.1016/j.fcr.2017.09.025 (2017).

Mason, S.C., and N.E. D’Croz-Mason. 2002. Agronomic practices influence maize grain quality. J. Crop Prod. 5: 75-91.

Mohammed, A., Samir, G.A. and Fathy, S.E.(2014). Effect of integrated use of organic and mineral fertilizer on some quality parameters of maize (Zea mays L.).International J. Innovation \& Scientific Res.,9(2):228-236

Mubeen, K., Iqbal, A., Hussain, M., Zahoor, F., Siddiqui, M.H., Mohsin, A.U., Bakht, H.F.S.G., Hanif, M. 2013. Impact of Nitrogen and Phosphorus on the Growth, Yield, and Quality of Maize (Zea mays L.) Fodder in Pakistan. Philipp. J. Crop Sci. 38(2), 43-46

Naikwade, P.V., S.T. Sankpal and B.B. Jadhav. 2012. Management of waste by composting, vermicomposting and its use for the improvement of growth, yield, and quality of fodder maize. ARPN J. Sci. Technol. 2: 184-194.

Negassa W., Tolera A., Friesen DK, Abdenna D. and; Berhanu D. 2004b. Evaluation compost for maize production under farmers' conditions. In: Friesen DK and Palmer AFE. (Eds.). Integrated Approaches to higher maize productivity in the new millennium: Proceedings of the Seventh Eastern and Southern African Regional Maize Conference, 5-11 February 2002, Nairobi, Kenya:

Okalebo JR, Nandwa S (1997) Effect of organic materials with and without mineral fertilizers P fertilizer on 
maize yield mainly in P deficient soil. Report on Activity 3.1.1. Soil Fertility and Plant Nutrition Research Programme, KARI, EU Funded, Europe.

Okalebo, J.R., Gathua, K.W. and Woomer, P.L. 1993. Laboratory Methods of Soil and Plant Analysis: A working manual. TSBF-UNESCO, Nairobi, EPZ Publishers, Nairobi, Kenya, 88p.

Palm CA, Gachengo CN, Delve RJ, Cadisch G, Giller KE (2001) Organic inputs for soil fertility management in tropical agroecosystems: application of an organic resource database. Agri Ecosys Environ 83: $27-42$.

Sarwar, M. (1993). Effect of different levels of N fertilizers on the yield and quality of maize. Pak. J. Agri. Sci. 30: 99-101.

SAS (Statistical Analysis System Institute). 2014. SAS Version 9.4 (C) 2002-2012. SAS Institute, Inc., Cary, North Carolina, USA.

Schro"der J. Revisiting the agronomic benefits of manure: a correct assessment and exploitation of its fertilizer value spares the environment. Bioresour. Technol. 2005; 96: $253-261$. https://doi.org/10.1016/j.biortech.2004.05.015 PMID: 15381224

Sheikha EAF. Mixing manure with chemical fertilizers, why? And what is after? Nutr. Food Technol. 2016; 2: $1-5$.

Shilpashree V M, Chidanandappa H M, Jayaprakash R and Punitha B C. 2012. Influence of Integrated. Nutrient Management Practices on Productivity of. Maize Crop. Indian Journal of Fundamental and Applied Life Sciences 2(1): 45-50.

Shisanya CA, Mucheru MW, Mugendi DN, Kungu JB (2009) Effect of organic and mineral fertilizers nutrient sources on soil mineral nitrogen and maize yields in central highlands of Kenya. Soil Tillage Res 103: 239246

Sumner, M.E. 2000. Handbook of Soil Science, CRC Press, Boca Raton, FL.

Suthar S (2007) Production of vermi-fertilizer from guar gum industrial waste by using composting earthworm Perionyx sansibaricus (Perrier). Environmentalist 27: 329-335.

Suthar S (2009) Bioremediation of agricultural wastes through vermicomposting. Bioremed J 1: 10-16.

Tekalign Tadese. 1991. Soil, plant, water, fertilizer, animal manure, and compost analysis. Working Document No. 13. International Livestock Research Center for Africa, Addis Ababa, Ethiopia.

Thomison, P.R. and A.B. Geyer. 2004. Nitrogen fertility effects on grain yield, protein, and oil of corn hybrids with enhanced grain quality traits. Plant Manage. Network. 15: 24-27.

Usman M, Madu VU, Alkali G (2015) The combined use of organic and mineral fertilizers for improving maize crop productivity in Nigeria. Int J Sci Res Pub 5: 1-7.

Wang XL, Ren YY, Zhang SQ, Chen YL, Wang N. Applications of organic manure increased maize (Zea mays L.) yield and water productivity in a semi-arid region. Agricultural Water Management. 2017;187: 88-98.

Waseem MA, Giraddi RS, Math KK (2013) Assessment of nutrients and microflora in vermicompost enriched with various organics. J Exp Zool India 16: 697-703.

Yadav KD, Tare V, Ahammed MM (2010) Vermicomposting of source-separated human feces for nutrient recycling. Waste Manag 30: 50-56.

Zhao J, Ni T, Li J, Lu Q, Fang ZY, Huang QW, et al. Effects of organic-mineral fertilizers compound fertilizer with reduced chemical fertilizer application on crop yields, soil biological activity, and bacterial community structure in a rice-wheat cropping system. Applied Soil Ecology. 2016; 99: 1-12. 